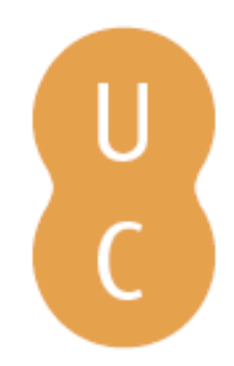

\title{
pommalina
}

\section{Studying the implementation of governmental accounting reforms: reflections on possible contributions of the Actor-Network Theory}

\author{
Autor(es): Sébastien, Rocher \\ Publicado por: Imprensa da Universidade de Coimbra \\ URL \\ persistente: URI:http://hdl.handle.net/10316.2/32182 \\ DOI: $\quad$ DOI:http://dx.doi.org/10.14195/978-989-26-0422-0_11 \\ Accessed : $\quad$ 26-Apr-2023 00:29:45
}

A navegação consulta e descarregamento dos títulos inseridos nas Bibliotecas Digitais UC Digitalis, UC Pombalina e UC Impactum, pressupõem a aceitação plena e sem reservas dos Termos e Condições de Uso destas Bibliotecas Digitais, disponíveis em https://digitalis.uc.pt/pt-pt/termos.

Conforme exposto nos referidos Termos e Condições de Uso, o descarregamento de títulos de acesso restrito requer uma licença válida de autorização devendo o utilizador aceder ao(s) documento(s) a partir de um endereço de IP da instituição detentora da supramencionada licença.

Ao utilizador é apenas permitido o descarregamento para uso pessoal, pelo que o emprego do(s) título(s) descarregado(s) para outro fim, designadamente comercial, carece de autorização do respetivo autor ou editor da obra.

Na medida em que todas as obras da UC Digitalis se encontram protegidas pelo Código do Direito de Autor e Direitos Conexos e demais legislação aplicável, toda a cópia, parcial ou total, deste documento, nos casos em que é legalmente admitida, deverá conter ou fazer-se acompanhar por este aviso.

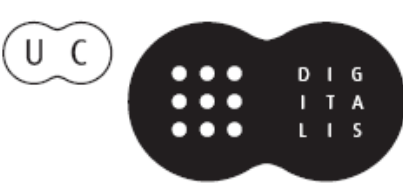




\section{Implementing Reforms in Public Sector Accounting}

Susana Jarge

Editor

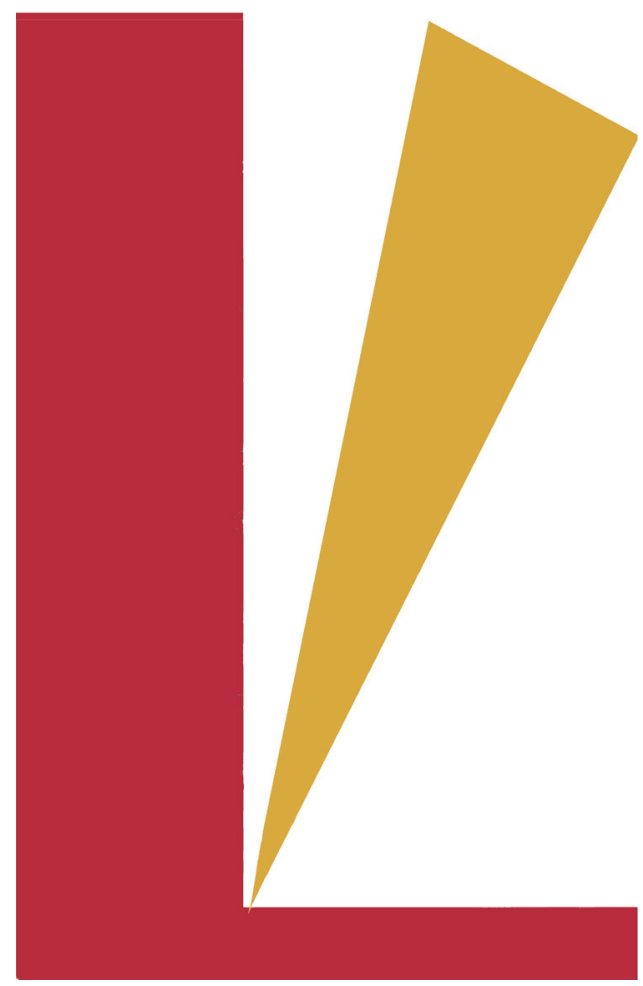


(Página deixada propositadamente em branco) 


\section{Implementing comparative Interational Reforms Governmental in Public Sector Accounting Accounting}

Susana Jorge Editor 
COORDENAÇÃO EDITORIAL

Imprensa da Universidade de Coimbra

Email: imprensauc@ci.uc.pt

URL: http://www.uc.pt/imprensa_uc

CONCEPÇÃO GRÁFICA

António Barros

\section{PAGINAÇÃO}

Simões \& Linhares, Lda.

\section{EXECUÇÃO GRÁFICA}

Simôes \& Linhares, Lda.

ISBN

978-989-8074-39-3

DEPÓSITO LEGAL

$281657 / 08$

\section{OBRA PUBLICADA COM O APOIO DE:}
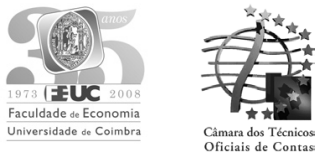

(C) Agosto 2008, IMPRENSA DA UNIVERSIDADE DE COIMBRA 
Rocher Sébastien

\section{STUDYING THE IMPLEMENTATION OF GOVERNMENTAL ACCOUTING REFORMS - REFLECTIONS ON POSSIBLE CONTRIBUTIONS OF THE ACTOR-NETWORK THEORY*}

\section{Introduction}

The Comparative International Governmental Accounting Research (CIGAR) network was created on the basis of contingent studies on governmental accounting reforms (Lüder, 1992, 1994 and 2002; Monsen and Nasi, 1998). Such studies give interesting insights into the context of accounting reforms and the conditions of their implementation through the analysis of environmental factors. At present, in the public sector, contingency models are notably used to provide comparative studies on accounting reforms at an international level (Jaruga and Nowak, 1996; Lüder, 1992 and 1994, Elwood, 2002) or national studies on the development of accounting reforms or new accounting systems (Yamamoto, 1999; Ter Bogt, 2006).

However, these approaches do not study the reform in itself and seem limited in terms of the implementation processes used (Chan et al., 1996; Monsen and Näsi, 1998; Ridder et al., 2005): for e.g., What does the reform become when confronted with resistance? How do the actors involved in the implementation process influence the contents of the reform and the techniques on which the reform is based and, conversely, how transformations of the reform influence actors? How and why actors with divergent interests confronted with a new accounting system cooperate in order to implement it? How reforms have come to be 'settled' as they are?

This paper is an answer to the call of Chan et al. (1996, quoted in Monsen and Näsi, 1997: 281) for further research on such questions as: Who came up with the original idea for an accounting innovation? How did he or she persuade others to adopt the new idea? What factors influenced the adoption decision? But instead of

\footnotetext{
* The author would like to acknowledge, with thanks, the help of Audrey Milton, Senior Lecturer, School of Business, James Cook University, Australia, for the numerous helpful comments she made on this paper. The author would also like to thank the anonymous referees for their comments on previous drafts of this paper.
} 
looking for answers based on positivistic orientations, the emphasis of this paper is on a constructivist approach of accounting reform. A socio-technical view of the construction of accounting reforms is employed and reference is made to Actor-Network Theory (ANT) (Callon, 1981 and 1986; Latour, 1987; Latour and Woolgar, 1979).

The aims of this article are to present the strengths of ANT in the study of the implementation of governmental accounting reforms, and to discuss how this approach could help to bring a complementary view of accounting reforms in the public sector at an international level.

The paper is organized as follows: in the next section, some limits of the Contingency Model are briefly discussed; then, some contributions of ANT to the study of accounting system implementation are presented before concluding remarks.

\section{Some Limits of the Contingency Model of Governmental Accounting Reforms}

Many criticisms are directed towards the Contingency Model used in the study of governmental accounting reforms and contingency studies in general. Even if the application of the contingency model offers the possibility to make international comparison and has created a whole new field of research in public accounting, and even if the contingency model of governmental accounting innovations has never ceased to evolve since its first version by incorporating more and more variables (Lüder, 1992, 1994 and 2002; Jaruga and Nowak, 1996; Godfrey et al., 2001; Monsen and Näsi, 1997), it still presents majors limits.

Among them, four main limits can be evidenced. Firstly, many contingency studies provide disparate results, sometimes completely contradictory (See, for example, the criticisms addressed by Chapman, 1997, and Gerdin and Greve, 2004). The main consequence of this is the difficulty of building a common framework on which further studies could be built.

Secondly, contingency studies rely on a static view of innovation. Indeed, contingency studies are based on a rationalistic and deterministic view of innovations, based on well-defined techniques, accepted on the basis of their intrinsic characteristics and their capacity to overcome any resistance with which they may be confronted (Chapman, 1997; Ter Bogt, 2006). Contingency studies in accounting are no exception. In accordance with Robson (1991: 547) "most contingency-type models of accounting are synchronic, in that they relate a certain static mode of accounting functioning to the existence of particular environmental variables".

Thirdly, contingency studies on governmental accounting reforms consider reforms as 'black boxes' (Monsen and Näsi, 1998; Chan et al., 1996; Chan, 2002; Lüder, 2002). In accordance with Callon and Latour (1981: 285) "a black box contains that which no longer needs to be reconsidered, those things whose contents have become a matter of indifference". In other words, reforms at the basis of contingency studies are rarely explored or analysed. Many authors agree on the necessity to overcome this third limit (Chan et al., 1996; Chan, 2002; Lüder, 2002; Rocher, 2006). Chan (2002: 25) argues that if "the CIGAR literature has so far tended to stress 'context' over 'content', content is important: it tells us about what a government accounting and reporting system does. For example, who supplies what financial information to whom? When? 
How? And to what ends? Answers to these questions in different national contexts would reveal the sources of the similarities and differences in the scope and function of accounting."

Fourthly, besides the addition of behavioural criteria in the contingency model used to study governmental accounting reforms (Lüder, 2002), the relation between the reform and the actors remains incomplete. The distinction made between users and producers of accounting information is questionable. Monsen and Näsi (1998: 283) proposed to modify it because actors can play two or more roles simultaneously or in different time periods: "For example, an administrative actor is simultaneously a citizen. $\mathrm{He} / \mathrm{she}$ is therefore also a member of the electorate as well as a service receiver from the governmental organization. He/she may also occupy the role of politician" (1997: 283). Yet, it seems also possible to criticize the distinction between users and producers based on the results of accounting studies, which show that users and producers of accounting studies are not definitive positions. For example, certain users temporarily transform the original usage of accounting information (information and decisionmaking) when they use it as a tool of legitimation, rationalization or argumentation (Burchell et al., 1980; Hopwood, 1990). In so doing, they temporally become producers of a 'different' accounting information. Moreover, many studies highlight that actors involved in the implementation of an accounting system, independently seen as users or producers, are not passive vectors: they can refuse it, accept it, modify it by adding elements of their contents or adapt it by integrating it in new environments (Robson, 1991; Preston et al., 1992; Lowe 2001a and 2001b; Quattrone and Hopper, 2005).

Lüder (2002: 6), answering critics of the weaknesses of the Contingency Model, recalls, however, that the model "is exclusively aimed to permit an assessment of conduciveness of relevant environmental factors prevailing in a country to governmental accounting innovations. Its aim, however, is not to explain the whole reform process including all relevant factors" and sees all these critiques as new directions for future studies.

It appears that the Actor-Network Theory (ANT) could provide interesting answers to the limits of the Contingency Model and respond to some expectations of researchers involved in the CIGAR network and to practitioners confronted with governmental accounting reforms.

\section{An alternative approach: the Actor-Network Theory}

Because ANT has already been used in many accounting studies (Chua, 1995; Lowe, 2001a and 2001b; Quattrone and Hopper, 2005; Lowe and Koh, 2007) and introduced to accounting researchers, this approach will not be discussed in detail here (see, for example, Robson, 1991; Preston et al., 1992; Lowe, 2001a; Baxter and Chua, 2003). Only its implication to the understanding of the implementation of governmental accounting reforms will be presented.

In accordance with Chua (1995) the reference to ANT is justified because "ANT can help to understand the change of the organisational reality engendered by the controversies of the experimentation of new accounting techniques or reforms; to overcome the positivistic assumption that a set of accounting numbers is rationally 
accepted because it more accurately represents reality. Instead, the ANT approach is based on the idea that reality is socially constructed."

\subsection{An approach based on a 'dynamic' vision of innovation}

The ANT is based on a 'dynamic' vision of innovations, contrary to the static vision advocated by contingency studies. It rests on a socio-technical view of innovation, that is to say a combination of social and technical aspects. Indeed, ANT is based on the idea that any innovation is the result of a continuous process of interessment of an increasing number of actors with different origins (professional, social, human or not human... $)^{2}$ and divergent interests around the same project. The creation and the consolidation of such networks is the key to the development of an innovation. However, the search for the cooperation of actors with divergent interests gives birth to controversies which lead to 'translation' processes. Latour (1987: 108) defines translations as the "interpretation given by the fact builders of their interests and that of the people they enrol". The concept of translation refers to the process through which divergent interests of actors in conflict are transformed into facts in order to reach a common interest. Only after this process is the possibility of the emergence of a network of actors around the same project. In accordance with this definition, Quattrone and Hopper (2005: 737), referring to ANT, underline that "accounting representations [...] only emerge after a process of translation involving mediations between various interests and existing technologies that redefine their attributes and why they were introduced."

So, contrary to contingency studies which are based on a positivist point of view, the ANT is founded on a constructivist view of the innovation.

\subsection{An approach centred on the continuous interactions between actors and techniques}

Consequently, the acceptance of, and the institution of an accounting system can be represented as the adequacy between the number of allies associated with the project and the necessary transformations of the project to reach that point, in accordance with Latour (1988: 33) who stated that "every socio-technical imbroglio may be defined by two dimensions. First, how many people are convinced and take it as an incontrovertible black box; secondly, (if it is interrupted by people who doubt it and wish to open the box), what sort of transformations has the project to undergo in order to convince more people, that is, what sort of fresh non-human allies have to be fetched?" (Figure 1).

\footnotetext{
${ }^{2}$ Latour (1996) refers to the concept of 'actants' to extend the word actor to non-human, non-individual entities. An actant is "something that acts or to which activity is granted by others. It implies no special motivation of human individual actors or of humans in general". This definition is derived from the semiotic definition of the term 'actor' by Greimas (1979): "Whatever unit of discourse in invested of a role" (Callon and Latour, 1981).
} 
Figure 1 - The innovation process

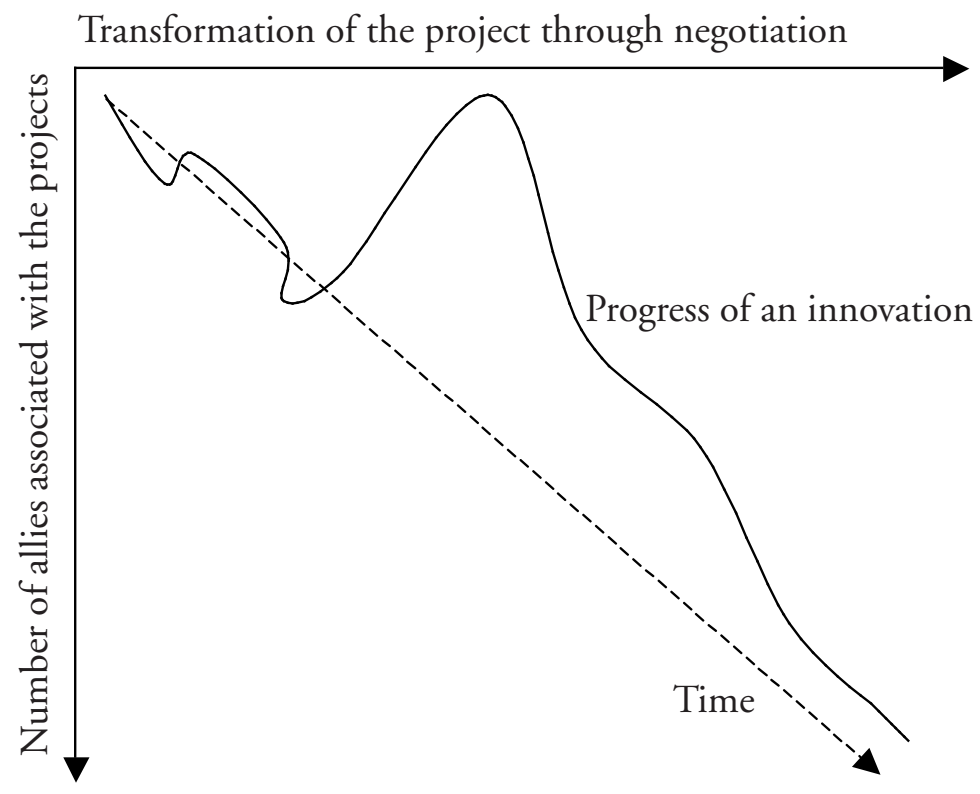

Source: Adaptation from Latour (1988).

The search for an increasing number of actors interested in the accounting system leads to negotiations, displacements and modifications of the project in order to make it correspond to an increasingly large whole of the interests involved. As stated by Latour (1988: 34) "From the beginning to the end it [the innovation process] never stops being the resultant of a fourfold strategy: Whom should I convince? How strong is the resistance of those I choose to convince? What new resources should I enrol? What transformations should the project undergo?"

\subsection{An approach based on the understanding of how black boxes are instituted}

The temporal dimension in Figure 1 highlights how the successive transformations of the project make it become progressively the gathering point of the actors interested in it. So, in accordance with Latour (1987: 258), in order to study the fabrication of technical artefacts, it is necessary to "study science in action and not ready made science or technology; to do so, we either arrive before the facts and machines are blackboxed or we follow the controversies that reopen them." ANT provides a good way to explain 'what happens' by focusing on the progressive construction of objects which are taken for granted in most studies, as governmental accounting reforms are taken for granted in contingency studies, for example. 


\section{Contributions of the Actor-Network Theory to the Study of Governmental Accounting Reforms}

Referring to ANT could bring alternative answers to the limits of contingency studies and provide interesting insights of governmental accounting reforms by: (1) highlighting the motivations of actors and the evolution of the reform and (2) providing an understanding of reforms at an international level.

(1) By applying ANT rather than a contingency model, the aim is not now to identify the external factors which influence the introduction or the implementation of an accounting reform without any consideration of the reform itself, but to analyse simultaneously the success or the failure of the constitution of networks of actants and the transformations (the translations) the reform has to undergo to 'keep alive' the interest of the actors involved. For example, instead of focusing on the external conditions of the introduction of accrual accounting in different government organisations, it is of interest to understand who were the actors involved? What were their interests in the reform? How do they remain interested or how do new actors become interested following transformations of the reform? How does the reform evolve, from its first ambition to its latest application? Why and how the actors transformed it?

These transformations could concern the operation framework or the usage framework which are constitutive of any accounting system. The operation framework refers to the knowledge and know-how which is utilised in the technical activity, while the usage framework relates to the real or perceived usage of the technique, whether it is about technical or social usage. Thus, in the case of accounting (seen as a technique), its operation framework calls upon much knowledge (the rule of the double part, the accounts subdivision...) and know-how (classification of the amounts in the adapted accounts, elaboration of standardized documents...). However, its use can be defined, on the one hand, in regard to the desired technical usage and, on the other hand, in comparison with the usage which is expected from it (respect of the laws, information of the internal and external actors, help in the decision-making process...). Nevertheless, operation framework and usage framework are not fixed. The interaction of one of these two frameworks implies, irremediably, an evolution of the other one, even if it was not aimed at initially. For example, the search for better accounting information in regard to the needs of users (which can be interpreted as a desired improvement of the usage framework) has consequences for accounting rules (modification of the operation framework). In France, the reform of budgetary instructions applied by local governments since January 1, 2007, is justified by the need to bring a response to the informational gaps of the accounting information (to have a healthy and effective use of credits, facilitate the understanding of budgets for elected officials and citizens, reduce the production costs...). But the achievement of these objectives was not possible without an evolution of the rules, which are the knowledge and know-how constitutive of the operation framework: transformation of the budgeting rules, evolution of the contents of the documents...

(2) Governmental accounting reforms could also be studied as their capacity to become a 'boundary object'. On the basis of ANT, Star and Griesemer (1989) show in the 
study of the creation of a museum of zoology on the American west coast, that cooperation of actors characterized by divergent interests and different representations passes through the emergence of 'boundary objects' common to the various categories of actors interested in the development of the museum. According to these authors, the emergence of boundary objects is the key of the cohesion of several social worlds around the same shared objective. Such objects are the results of the successive transformations of the reforms in order to regroup all the different interests of the actors in a shared representation.

Star and Griesemer (1989: 393) define boundary objects as "objects which are both plastic enough to adapt to local needs and the constraints of the several parties employing them, yet robust enough to maintain a common identity across sites. They are weakly structured in common use, and become strongly structured in individual site use. [...] They have different meanings in different social worlds but their structure is common enough to more than one world to make them recognizable, a means of translation. The creation and management of boundary objects is a key process in developing and maintaining coherence across intersecting social worlds." ${ }^{3}$ Briers and Chua (2001: 242) quote the example of the Activity-Based Costing (ABC) method and highlight the fact that many actors speak about this method because they share a common vision of what $\mathrm{ABC}$ is. However, the application of the method differs from one company to another. Consequently, the $\mathrm{ABC}$ method is a 'hard' unit, shared by all, with malleable contents, adaptable to each particular situation.

So, governmental accounting reforms could be understood in light of ANT. For example, even if many countries apply accrual accounting at present, few of them share the same definition of what it is and, in most cases, differences appear between expectations, rules and practices (Lüder and Jones, 2003). How does accrual accounting become a boundary object in (and for) many countries? What are the controversies and the translations it has been exposed to in order to be accepted? Answers to these questions in different national contexts would reveal the sources of the similarities and differences in the definition, the scope and the application of accrual accounting. Such studies could be done at an international level in order to give comparative insights of the transformations, the controversies, the resistances, the actors involved and their interactions with accrual accounting. The aim is not anymore to recognize the external factors which influenced the implementation of accrual accounting in different countries but rather looking for the path accrual accounting follows to be accepted in a particular manner in each country. These questions also seem relevant in the study of the application of international accounting norms, and the application of ANT could provide alternative explanations of the differences between the norms and their national application in term of 'translation', alliances of 'actants' or 'boundary objects'.

${ }^{3}$ Star and Griesemer (1989: 410) distinguish four main categories of boundary objects (Repositories, Ideal Standard, Coincide Boundaries and Standardized Forms) which are illustrated in an accounting context by Briers and Chua (2001). 


\section{Discussion}

According to Chan (2002: 25), "by definition, the task of CIGAR is to study how government accounting works in different nation-states." ANT provides an alternative framework to study 'accounting in action' and study the complexity of reform processes instead of simplifying it through a limited number of variables. By looking at the emergence of controversies between actors, transformations and evolutions of the reform which lead reciprocally to the evolution of the actors (in strengthening or weakening their interest in the reform and their participation to the reform process), ANT is a way, on one hand, to understand how innovations occur (Chan et al., 1996) and on the other hand, to pinpoint that what 'works' is the result of many unplanned negotiations and transformations (Lowe, 2001b).

Thus, it appears that ANT offers an interesting theoretical framework for studying analytical exploratory studies (to better understand the case studied) and for searching for a deeper explanation of common definitions and designs. These two directions are amongst the main directions Chan (2002) believes that future studies by CIGAR scholars should follow, rather than relying on descriptive exploratory studies or on the search for differences in definitions and designs. ANT also gives answers to some rhetorical questions asked by Chan (2002: 24), for example: How can the process of change be captured? How does government accounting work?

Finally, the application of ANT raises also methodological issues: because ANT is based on a constructivist view of innovation, the understanding of the evolution of a reform, the construction of networks of actors requires deep involvement of the researchers and raises the question of ethnographic studies as a way to study governmental accounting reforms.

\section{References}

Baxter, J. and Chua, W.F. (2003), Alternative Management Accounting Research - whence and whither, Accounting, Organizations and Society, Vol. 28, 97-126.

Briers, M. and Chua, W. F. (2001), The Role of Actor-networks and Boundary Objects in Management Accounting Change: A Field Study of an Implementation of Activity-based Costing, Accounting, Organizations and Society, Vol. 26, 237-269.

Burchell, S.; Clubb, C.; Hopwood, A.; Hughes, J. and Nahapiet, J. (1980), The Roles of Accounting in Organizations and Society, Accounting, Organizations and Society, Vol. 5, No. 1, 5-27.

Callon, M. (1981), Struggles and Negotiation to Define what is Problematic and what is not: the Sociology of Translation, in Knorr, K. D., Khon, R. and Whitley, R. (eds.), The Social Process of Scientific Investigation, Dordrecht: D. Reidel Publishing Company.

Callon, M. (1986), Some Elements of a Sociology of Translation: Domestication of the Scallops and the Fishermen of St Brieuc Bay, in Law, J. (ed.), Power, Action and Belief: A New Sociology of Knowledge, Routledge \& Kegan Paul, London and New York, NY, 196-223.

Callon, M. and Latour, B. (1981), Unscrewing the big Leviathan: How Actors Macro-structure Reality and how Sociologists Help them to do so, in Knorr, Karin D. and Cirourel, Aron (dir.), Advances in Social Theory and Methodology. Toward an Integration of Micro and Macro Sociologies, London: Routledge \& Kegan Paul, 277-303. 
Chan, J. L. (2002), Comparative International Government Accounting Research (CIGAR) methodology: issues and strategy, in Montesinos, V. and Vela, J. M. (eds.), Innovations in Governmental Accounting, Kluwer Academic Publishers, 23-29.

Chan, J. L.; Jones, R. H. and Lüder, K. G. (1996), Modelling Governmental Accounting Innovations: An Assessment and Future Research Directions, Research in Governmental and Nonprofit Accounting, 9, 1-19.

Chapman, C. S. (1997), Reflections of a Contingent View of Accounting, Accounting, Organizations and Society, Vol. 22, No. 2, 189-205.

Chua, W. F. (1995), Experts, Networks and Inscriptions in the Fabrication of Accounting Images: A Story of the Representation of Three Public Hospitals, Accounting, Organizations and Society, Vol. 20, No. 2/3, 111-145.

Elwood, S. (2002), Towards a Contingency Theory for Hospital Cost Accounting Systems: A Comparison of the UK and New Zealand, in Montesinos, V. and Vela, J. M. (eds.), Innovations in Governmental Accounting, Kluwer Academic Publishers, 265-281.

Gerdin, J. and Greve, J. (2004), Forms of Contingency Fit in Management Accounting Research-A Critical Review, Accounting, Organizations and Society, Vol. 29, 303-326.

Godfrey, A. D.; Devlin, P. J. and Merrouche, M. C. (2001), A Diffusion-contingency Model for Government Accounting Innovations, in Bac, A. (eds.), International Comparative Issues in Government Accounting, Boston et al: Kluwer, 279-296.

Hopwood, A. G. (1990), The Organizational and Behavioural Aspects of Budgeting and Control, in Arnold, J., Carsberg, B. and Scapens, R. (eds.), Topics in Management Accounting, University of Manchester, Philip Allen, 221-240.

Jaruga, A. and Nowak, W. A. (1996), Toward a General Model of Public Sector Accounting Innovations, Research in Governmental and Nonprofit Accounting, 9, 21-31.

Latour, B. and Woolgar, S. (1979), Laboratory Life, Sage, Los Angeles.

Latour, B. (1987), Science in Action. How to Follow Scientists and Engineers Through Society, Cambridge, MA: Harvard University Press.

Latour, B. (1988), The Prince for Machines as Well as for Machinations, in Elliot, B. (eds.) Technology and Social Change, Edinburgh University Press.

Latour, B. (1996), On Actor-network Theory: A Few Clarifications, Soziale Welt, 47, 369-382.

Lowe, A. (2001a), Reform of the New Zealand Health System: Problematization, Mobilization and Change, Policy Studies, Vol. 22, Nos 3/4, 233-249.

Lowe, A. (2001b), After ANT: An Illustrative Discussion of the Implications for Qualitative Accounting Case Research, Accounting, Auditing \& Accountability Journal, Vol. 14, No. 3, 327-351.

Lowe, A. and Koh, B. (2007), Inscribing the Organization: Representations in Dispute between Accounting and Production, Critical Perspectives on Accounting, 18, 952-974.

Lüder, K. G. (1992) A Contingency Model of Governmental Accounting Innovations in the Political-administrative Environment, Research in Governmental and Nonprofit Accounting, 7, 99-127.

Lüder, K. G. (1994) The "Contingency Model" Reconsidered: Experiences from Italy, Japan and Spain, in Buschor, E. and Schedler, K. (Eds.) Perspectives on Performance Measurement, Berne: Haupt, 1-15.

Lüder, K. G. (2002), Research in Comparative Governmental Accounting over the Last Decade - Achievements and Problems, in Montesinos, V. and Vela, J.M. (eds.), Innovations in Governmental Accounting, Kluwer Academic Publishers, 1-21.

Monsen, H. and Näsi, S. (1998), The Contingency Model of Governmental Accounting Innovations: A Discussion, The European Accounting Review, 7:2, 275-288.

Preston, A. M.; Cooper, D. J. and Coombs, R. W. (1992), Fabricating Budgets: A Study of the Production of Management Budgeting in the National Health Service, Accounting, Organizations and Society, Vol. 17, No. 6, 561-593. 
Quattrone, P. and Hopper, T. (2005), A “Time-Space Odyssey": Management Control Systems in Two Multinational Organisations, Accounting, Organizations and Society, Vol. 30, 735-764.

Robson, K. (1991), On the Arenas of Accounting Change: The Process of Translation, Accounting, Organizations and Society, Vol. 16, No 5/6, 547-570.

Star, S. L. and Griesemer, J. (1989), Institutional Ecology, ‘Translation' and Coherence. Amateurs and Professionals in Berkeley's Museum of Vertebrate Zoology, 1907-1939, Social Studies of Sciences, 19, 387-420.

Ridder, H-G.; Bruns, H-J. and Spier, F. (2005), Analysis of Public Management Change Processes: the Case of Local Government Accounting Reforms in Germany, Public Administration, Vol. 83, No. 2, 443-471.

Rocher, S. (2006), La consolidation des risques dans le secteur public local, unpublished doctoral thesis, University of Limoges, France.

ter Bogt, H. J. (2006), Financial Management of Housing Corporations in a Changing Environment: Economic and Social Rationality?, Financial Accountability \& Management, Vol. 22, Iss. 2, 107-132.

Yamamoto, K. (1999), Accounting System Reform in Japanese Local Governments, Financial Accountability \& Management, Vol. 15, Iss. 3/4, 291-307. 
(Página deixada propositadamente em branco) 


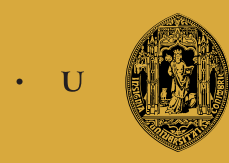

C - 